\title{
Authoritarian Neoliberalism: Periodization and Critique Bob Jessop
}

\author{
Abstract
}

Neoliberalism is variegated as different types of neoliberalism co-exist in a world market that is organized in the shadow of a neoliberalization process that began with neoliberal regime shifts in the USA and UK. This article provides a periodization of neoliberal regime shifts within this context, starting with their pre-history up to the point of no return and then tracing their roll-back, roll forward, blowback, 'Third Way', moments of financial crisis, and crisis of crisis-management phases. It argues that neoliberal regime shits were associated from their pre-history onwards with intertwined authoritarian populist and authoritarian statist discourses and practices. Nonetheless, the intensification and interaction of crisis-tendencies of different kinds in different phases and changing forms of resistance have led to an increasingly authoritarian statist form of neoliberal regime, characterized by a state of permanent austerity that requires increased surveillance and policing to maintain it. This illustrates Nicos Poulantzas's suggestion in the 1970s that authoritarian statism is becoming the normal form of the capitalist type of state but rests on the intensification of features normally associated with exceptional regimes. This article updates Poulantzas's argument to an era of finance-dominated accumulation and provides a new characterization of authoritarian neoliberal statism.

\section{Introduction}

Neoliberalism is a chaotic conception that is hard to define, especially if one aims to reveal what unifies specific instances as well as what makes them different. Refocusing attention on neoliberalization shifts the problem but does not solve it: we must still identify the outer limits of the concept and what causes its heterogeneity. Indeed, such refocusing adds a fresh problem. For, unless neoliberalization involves self-identical repetition, we must engage with its discontinuities as well as continuities over time as well as its variation or variegation across segments of timespace. This contribution cannot identify all the resulting challenges, let alone solve them. Instead, it provides one reading that explores the politics and policies of 
neoliberalization in one type of neoliberalism, namely, principled neoliberal regime shifts, which have the biggest impact on the world market and world of states. I also emphasize the contradictions and crisis-tendencies of neoliberal regime shifts and elaborate the barriers and ultimate limits to this process. A key aspect of this topic is the capacity of neoliberal regimes to displace and defer their contradictions elsewhere and into the future as well as to exploit other places and the past to maintain initial momentum (e.g., accumulation through dispossession, recruiting talent from non-neoliberal systems to compensate for weak investment in skills, or encouraging unskilled migrant labour to drive down wages in the domestic economy).

\section{Of varieties and variegation}

There is no consensus on how best to explore and explain the unity and heterogeneity of neoliberalism. In the case of capitalism, four methods are used: taxonomy, ideal-types, cluster analysis, and logical-historical analysis (Jessop 2014). Three of these methods are also used in the study of neoliberalism. Based on empirical observation and aiming at completeness, taxonomists distinguish several 'families', especially in advanced economies, with some attention to subordinate genera and species. Typologies are guided by theoretical considerations and most useful when just a few ideal types are used to disclose the complexity of actual cases with their hybridity, impurity, and 'cocktails' character. Cluster analysis uses statistical induction to identify clusters (and sub-clusters) and potential outliers, based on within-cluster similarity on multiple criteria and/or on the weight of revealed latent factors. Rarely used in analysing neoliberalism as such, this method is applied in studying the impact of neoliberalization on different welfare regimes. Finally, the logical-historical approach uses theoretically-informed comparison to move from abstract-simple categories to concrete-complex cases, often leading to the modification of concepts in the course of the analysis. Using this method, every case will eventually appear to be historically unique and liable to change over time. This is the method employed below.

Based on theoretical considerations and historical observation, four main forms of neoliberalism can be distinguished analytically. These may exist in hybrid forms and, 
depending on their contradictory and crisis-prone evolution, different forms may also succeed each other in the same economic and political space.

The first type is neoliberal system transformation in post-Soviet successor states. Two contrasting cases are Russia's Chicagoan 'creative destruction' induced by neoliberal shock therapy and Poland's more Ordoliberal 'market therapy without shock'.

Second are principled neoliberal regime shifts. Thatcherism and Reaganism are well-known cases. Breaking with post-war Atlantic Fordist social compromises, at least six neoliberal policies were pursued to modify the balance of forces in favour of capital. These policies comprise: (1) liberalization to promote free market competition or at least greater market competition; (2) deregulation, inspired by the efficient market hypothesis and belief in the prudential, self-preserving instincts of companies and financial institutions; (3) privatization to expand the profit-oriented, marketmediated economy and encourage efficient allocation of resources and capital's dynamic innovative potential; (4) introduction of market proxies in the public sector to favour efficient, effective, and economical delivery of public services, thereby undermining non-market values and logics, especially when combined with spending cuts; (5) reductions in direct taxation on corporate income, personal wealth, and personal income - especially on (allegedly) entrepreneurial income - to encourage economic agents to earn, save, invest, innovate, create, and accumulate individual and corporate wealth rather than allowing the state to determine the level and content of national output; and (6) internationalization to complete the world market through the free flow of goods and services, profit-producing investment and technology transfer, and the mobility of interest-bearing capital. While often identified with right-wing parties, these shifts have also been initiated or supported by centreleft parties.

Type three comprises neoliberal economic restructuring and regime shifts that occurred in response to inflationary and/or debt crises in (semi-)peripheral economies. These changes were imposed from outside by transnational economic institutions and organizations led by major capitalist powers and backed by partners in the political and economic elites in affected countries. Neoliberalization was a 
condition for aid to crisis-ridden economies in parts of Africa, Asia, Eastern and Central Europe, and Latin America. While the second and third types often pursue similar policies in the (semi-)periphery of the global economy, they have analytically distinct roots.

Fourth are more pragmatic and potentially reversible neoliberal policy adjustments. Not all of the six neoliberal economic policies are adopted in such cases because this type involves more modest and piecemeal changes deemed necessary by governing elites and their social base(s) to maintain existing economic and social models in the face of specific crisis-tendencies and the challenges generated by growing world market integration. In Europe, the Nordic social democracies and Rhenish capitalism provide examples. However, such adjustments can cumulate and, as if by stealth, lead to neoliberal regimes (witness Germany in the last 25 years). Moreover, following the North Atlantic Financial Crisis (hereafter, NAFC) and the Eurozone crisis, these cumulative changes have become harder to reverse as global pressures and the EU's approach to crisis-management tend to reinforce neoliberalization. This can be seen in efforts to institutionalize neoliberalism in a succession of pacts and crisis-management responses in the Eurozone economies.

\section{On periodization}

As no social order is reproduced identically, attention is required to its transformations and substantive changes. A fortiori, this holds for neoliberalism. This is reflected in different chronologies and attempts at periodizing neoliberalism. Chronologies order selected actions and events in unilinear time and divide their development into stages according to the simple temporal succession or coincidence of a single series of actions and events in and across time periods demarcated by the calendar and/or some other socially relevant markers such as business cycles, crises, elections, or significant environmental events. This lends itself to simple narratives or policy narratives of how neoliberalism developed, idiographic explanations that focus on the unique unfolding of a series of events, or subsuming

particular cases under general or generalizing accounts. Many accounts of neoliberalism and/or neoliberalization take this form. 
Periodization relates one or more series of historical events to other significant events or interests and seeks to explain them without relying exclusively on a narrative. It orders actions and events in terms of multiple time horizons (e.g., eventalization, trends, the longue durée; the time-frame of economic calculation vs the time-frame of political cycles; or past futures, present pasts, and future presents). This approach explores complex conjunctures with ontological depth and breadth that reflect multiple temporalities, spatialities, etc. An important feature of periodization is its adoption of a strategic-relational approach that divides actions and events into stages based on their conjunctural implications (as specific mixes of constraints and opportunities) for different forces over different time horizons and/or for different sites of social action. This implies that there should be different periodizations of neoliberalization depending on the social forces that concern disinterested observers or particular participants. Thus, they would vary according to whether, for example, too-big-to-fail banks, small and medium enterprises, organized labour, undocumented migrants, global cities, or declining industrial towns provide the strategic focus. I now illustrate some of these arguments from neoliberal regime shifts in their Anglo-Saxon heartlands and, in later sections, address this mainly from the strategic perspective of financial capital.

Neoliberalization in these cases has seen seven main stages to date. The first comprises its pre-history as an intellectual, ideological and political movement up to "the point of no return", i.e., when the momentum behind a neoliberal regime shift made it likely that a party committed to neoliberal policies would enter office with a popular mandate or in coalition. Stage two consolidates a government committed to a neoliberal agenda and involves efforts to establish control over the legislature and executive branch in the face of opposition inside the government or from other forces. Consolidation initially focused on shifting the balance of forces through a mix of short-term concessions, passive revolution, concerted efforts to win hegemony and, in extremis, use of police powers to overcome resistance. This process may overlap with the third stage, namely, attempts to roll back the institutions and institutionalized compromises associated with the Atlantic Fordist post-war settlement. A key aim of stages two and three was to translate the discursive politics of free markets and a liberal state into substantive policy initiatives to remove obstacles to the neoliberal project. Fourth come efforts to roll forward neoliberal 
institutions, consolidate the shift in the balance of forces, and constitutionalize neoliberal principles nationally and, where possible, regionally and globally - making them harder to reverse even were the political conjuncture to turn temporarily against continued neoliberalization.

The fifth stage was blowback as the one-sided emphasis on serving mobile exportoriented profit-producing capital and interest-bearing capital led to resistance from disadvantaged capitals, intensified uneven development, increasing inequalities of income and wealth, provoked debt-default-deflation dynamics, and resistance from subaltern groups. This is the moment of the "Third Way" and analogous attempts to provide flanking and supporting mechanisms to maintain the neoliberal momentum.

Stage six was initiated by the irruption of the NAFC. While this initially signified a crisis of finance-dominated accumulation regimes, it did not produce a crisis of neoliberalism in the US and UK. For, while financial capital may have lost some credibility, it still dominated the accumulation regime, key parts of the administration, and, in the USA, the legislature. Toxic assets and losses were socialized at the expense of households, the public debt, and industrial capital. Financial crisis was translated discursively and practically into public debt and fiscal crises and intensified neoliberal vilification of state spending, with calls for further austerity measures.

Stage seven emerged in the context of the sixth stage. Thanks to its dominance in the power bloc, financial capital was able to manoeuvre to delay, dilute, and otherwise weaken attempts to re-regulate its operations at the expense of the public purse and future crises. This created the conditions to transform a crisis of financedominated accumulation into a crisis in this accumulation regime. At the same time, efforts continued to transform neoliberal austerity policies and politics into a permanent, constitutionalized state of austerity that undermine the institutions and practices of liberal democracy (Bruff 2014; Jessop 2016). This stage is elaborated below.

\section{Authoritarian populism and authoritarian statism}


The origins of Thatcherism as a qualitatively new stage in British politics and, later, British, European and Atlantic political economy were traced by Stuart Hall and his associates to the crisis of the post-war class compromise and Keynesian welfare state. They charted the rise of an exceptional form of representative state skewed towards the coercive, disciplinary pole of state power at the expense of the consensual, hegemonic pole (Hall et al., 1975: 218-323). This shift was mediated through the rise of "authoritarian populism" (AP). This political imaginary condensed a wide range of popular discontents with the post-war economic and political order and mobilized them around an authoritarian, right-wing solution to the intensifying economic and political crises in Britain. It signified a convergence between the demands of those in authority and the pleas of the populace for government to solve these crises. This analysis is especially relevant to the first and second stages of neoliberalization (see above) and this justifies Hall's emphasis on discursive and ideological struggles and the social bases of the neoconservative and neoliberal currents fused unevenly into the Thatcherite project. However, while his analysis remains relevant to other stages, these also require more attention to the institutional architecture of the state, the recomposition of the power bloc, and the restructuring of the British space economy and its differential insertion into the world market. Hall and his associates dealt with some of these issues in terms of "passive revolution", that is, a social transformation that occurs without mass mobilization through the accumulation of small-scale, "molecular" changes and/or through the top-down imposition of change. In this context, Hall sometimes interpreted AP as a passive revolution from above, sometimes as a passive revolution from below, thereby rendering ambiguous its authoritarian and populist qualities. Moreover, in focusing on these issues, his analysis understates potential sources of contradiction and tension within Thatcherism and subsequent stages in the neoliberalization process, as sketched above (for an early critique, see Jessop et al., 1988).

Also writing in the 1970s, Nicos Poulantzas identified the "irresistible rise" of authoritarian statism (hereafter AS). While Hall's analysis was focused on the British case, authoritarian populism can be seen in other cases of neoliberalization up to and beyond the "point of no return" and retains its heuristic and explanatory power. The AS concept was developed to describe a specific stage in the development of the normal form of the capitalist state in advanced capitalism. In this sense, it is 
potentially relevant to all stages in neoliberalization, especially if one takes account of the crisis-tendencies of this state form and their links to other economic and political crisis-tendencies. According to Poulantzas, the capitalist state is now "permanently and structurally characterized by a peculiar sharpening of the generic elements of political crisis and state crisis" (1978: 206). Political features that were previously exceptional and temporary are being normalized as "intensified state control over every sphere of socio-economic life [is] combined with radical decline of the institutions of political democracy and with draconian and multiform curtailment of so-called 'formal' liberties" (1978: 203-4). These developments emerged in response to the long-term structural economic crisis of a post-war capitalism, its reflection in political and ideological crises, an increasing internationalization of industrial and financial capital, a concomitant sharpening of contradictions within the power bloc, and the fracturing the class compromises and social bases that underpinned the interventionist state that had emerged pari passu with monopoly capitalism. These factors created problems for the interventionist state in performing its specific techno-economic, juridico-political, and ideological functions and, more generally, its overall function in organizing the power bloc and disorganizing the dominated classes and subaltern groups. The internationalization of capital made it harder to organize the power bloc and led to increasing intervention in all spheres of social life to promote competitiveness and discipline the population. This provoked new lines of conflict and stimulated the rise of new social movements and populist reaction against the enlarged state. In addition, Poulantzas noted, increasing world market integration makes it harder to displace or defer crises.

Writing in the mid-1970s, Poulantzas largely ignored authoritarian statist tendencies at the European and transnational levels as new forms of global governance were promoted to match the increasing integration of the world market. Of special interest here are the development of parallel power networks that connect national territorial states and seek to govern the space of flows; and the development of what Stephen Gill (1995) has labelled a "new constitutionalism". This provides super-protection for transnational profit-producing and interest-bearing capital as the neoliberal project is rolled out globally, limiting the territorial and temporal sovereignty of national states, and creating new extra-territorial mechanisms to adjudicate disputes. These measures aim to re-scale quasi-constitutional protections for capitalist enterprises 
and their activities to the international level (removing them from the contentious field of national politics); to transfer adjudication over disputes (including with states) to private tribunals, experts, lawyers, and other ostensibly non-political forums and/or figures; and, surprisingly (or not) in allegedly democratic regimes, to limit the power of elected governments to introduce legislation or administrative rules that would harm the anticipated profits of transnational enterprises. I return to this topic below.

Just as Hall's analysis of authoritarian populism was imprinted by the initial conjuncture of the rise of Thatcherism, from its diverse roots through the point of no return to its early consolidation, Poulantzas's account of authoritarian statism was shaped by the crisis of Atlantic Fordism as an accumulation regime, mode of regulation, and societal configuration and the state's attempts to manage this crisis and/or prepare the grounds for renewed capital accumulation in line with one or more post-Fordist economic imaginaries. Yet the analyses of both Hall and Poulantzas can be reworked for subsequent stages in neoliberalization and in the light of the transition from Atlantic Fordism to finance-dominated accumulation oriented to the world market.

\section{Finance-dominated accumulation}

Building on the preceding arguments, I now consider the political economy context of later stages of neoliberalization, whether primarily in the form of principled neoliberal regime shifts or primarily in the form of pragmatic neoliberal policy adjustments. The initial political economy context was the crisis of Atlantic Fordism, which took variegated forms within transatlantic economic space and the wider world market. Pragmatic neoliberal policy adjustments are associated with defence of the post-war social order and class compromise and modernization of existing accumulation regimes and modes of regulation in line with a new hegemonic economic imaginary, namely, the knowledge-based economy and financial innovation, with its implications for new strategies for economic, institutional, and societal competitiveness. In contrast, the forces behind neoliberal regime shifts have used the latter strategically to promote the transition towards a more radical and wide-ranging financedominated accumulation regime. 
The role of the state, broadly understood in the Gramscian sense of "political society + civil society", in promoting finance-dominated accumulation indicates that, far from being the product of spontaneous market forces and signifying the primacy of the economy, this regime is the product of political mobilization by interest-bearing capital and depends on a primacy of the political. Its rise, consolidation, and crisismanagement are linked to "unusual deals" with political authority (such as the exchange of financial contributions for administrative, judicial, fisco-financial or commercial decisions that privilege particular capitals and fall well outside the normal working of the rule of law), profit on the market from force and domination (including the use of state power to impose neoliberal rules, institutions and practices on other accumulation regimes and open up new fields of accumulation), and predatory political profits (including kleptocracy, accumulation based on dispossession, and so on). Moreover, as has been demonstrated in each major financial crisis, when crises occur, governments rescue financial institutions that are too big, too systemically important, or just too well-connected to be allowed to fail and pass the costs onto the "little people". In short, finance-dominated accumulation extends and deepens earlier forms of political capitalism in advanced post-war societies and leads to major changes in the circuits of capital as interest-bearing capital forms closer ties to the state apparatus.

In this context, I distinguish between finance, financial capital, financialization, finance-led growth, and finance-dominated accumulation. At stake in neoliberalization in the context of neoliberal regime shifts is the promotion of financedominated accumulation. The six features of the neoliberal policy set facilitate the disembedding of capital from local material, social, and spatio-temporal constraints as well as the frictions of national power containers and national politics. This intensifies the influence of the logic of capital on a global scale as the global operation of the law of value (i.e., the allocation of capital to different activities in the light of expectations about future profits) commensurates local conditions across space-time and also promotes the treadmill search for superprofits. Neoliberalization contributes to the completion of the world market by facilitating the deepening of the spatial and scalar divisions of labour, by creating more opportunities for moving up, down, and across scales, by commodifying and securitizing the future, and by rearticulating time horizons through space-time compression and time-space 
distantiation. Thus it helps to free monetary accumulation from extra-economic and spatio-temporal constraints, increases the emphasis on speed, acceleration, and turnover time, and enhances capital's capacity to escape the control of other systems insofar as these are still territorially differentiated and fragmented. It also enhances capital's opportunities to displace and/or defer its contradictions and negative externalities onto other economic actors and interests, other systems, and the natural environment.

In this context, interest-bearing capital gains strongly from world market integration because it controls the most liquid, abstract, and generalized resource and because it has become the most integrated fraction of capital. As finance-dominated accumulation expands and penetrates deeper into the social and natural world, it transforms the micro-, meso- and macro-dynamics of capitalist economies. First, it alters the calculations and behaviour of non-financial firms through the rise of shareholder value as a coercive discourse, technology of governance, and vector of competition. One aspect is the growing importance for non-financial firms of financial activities (e.g., treasury functions, financial intermediation, using retained profits for share buybacks and/or acquisition or expansion of financial subsidiaries) that are not directly tied to their main profit-producing pursuits (Krippner 2005; Lapavitsas 2013). Second, it boosts the size and influence of the financial sector. Fee-producing and risk-taking activities increase relative to banking capital's more traditional roles in intermediation and risk management; securitization, leverage and shadow banking with corresponding liquidity risks and weak prudential controls also expand; and so does the significance of new forms of financial capital (e.g., hedge funds, private equity, vulture capital, sovereign wealth funds). Third, as successive crises from the mid-1970s show, financialization makes the economy more prone to recession and, in severe cases, more liable to the downward spiral of debt-deflation-default dynamics (Duménil and Lévy 2005; Fine 2010; Lapavitsas 2013; Rasmus 2010). Indeed, as more scandals emerge in the financial sector, it is becoming clear that these superprofits derive in part from predatory and, indeed, criminal activities that were facilitated by successive measures of deregulation enacted thanks to the financing of political parties and unusual deals with political bodies (Smith 2010; Will, Handelman and Brotherton 2013; Black 2014). 
Because continued expansion depends heavily on the pseudo-validation of highly leveraged speculative and Ponzi debt, finance-dominated accumulation contains its own inherent crisis-generating mechanism rooted in the systemic conflict between interest-bearing and profit-producing capital. Wolfram Elsner (2012) explains this as follows. Financial capital in this regime has a target rate of return that is several times greater than the historic norm for profit-producing capital and, worse still, by striving to achieve this target, it engages in massive leveraging of fictitious credit and capital. In aggregate, the eventual validation of this massively leveraged capital would demand a total volume of surplus-value that far exceeds the productive and exploitative capacity of existing profit-producing capital.

The overaccumulation of financial capital enabled by its dissociation from, and indifference to, other moments of the capital relation was a crucial factor contributing to the eventual bursting of financial bubbles around the world. But the crisis has a specific form due to the hyper-financialization of advanced neoliberal economies and, in particular and most immediately, the practices of de-regulated, opaque, and sometimes fraudulent financial institutions that still benefit from a corrupt relation with political authority. These features reflect the hybrid nature of finance-dominated accumulation through its articulation with a predatory and parasitic political capitalism. Overall, the hierarchy of structural forms in this regime generated an epic recession, and perhaps eventually, another great depression, which is based on the vicious interaction among debt, default, and deflation (Rasmus, 2010).

\section{Authoritarian neoliberal statism}

There is a familiar argument, advanced from left, centre, and right political positions, that liberal bourgeois democracy provides the best possible political shell for profitoriented, market-mediated capital accumulation. The form of this democratic shell changes with the dominant accumulation regime, its articulation to other regimes and modes of production, and the extent and forms of world market integration. Whether or not liberal bourgeois democracy is stable depends in part on the ability to reconcile the granting of universal franchise to all citizens, regardless of their class location or position within other social hierarchies, and the imperative that the state maintain the conditions for economic exploitation and political domination. This is 
generally achieved through a successful strategy aimed at securing bourgeois "hegemony protected by the armour of coercion" (Gramsci 1971). Economic crises as such do not necessarily destabilize hegemony but where they occur in the context of political crises, especially crises within the power bloc and crisis of hegemony over the people, there is a serious threat to economic and political order. It is in this context that attempts are made to declare a more or less radical and more or less enduring exceptional state. These can take different forms, ranging from a government of national unity, technocratic or bureaucratic rule, military dictatorship, fascist state, and so forth. This may be accompanied by authoritarian populism and/or authoritarian statism. The significance of Poulantzas's analysis in this regard lies in his suggestion that AS is the normal form of the capitalist state as the crisis of Atlantic Fordism intensifies, and exceptional measures are needed to manage that crisis and manage the transition to a new economic regime.

This raises the interesting question concerning the nature of the best possible political shell in the neoliberal era. For ordoliberals, this would be a strong state based on the rule of law that establishes the conditions for profit-oriented, marketmediated accumulation able to compete in the world market and that has sufficient competences and capacities to intervene against unfair competition and to compensate for market failures and negative externalities. This was the original Social Market Economy model. It would provide a formally adequate institutional and spatio-temporal fix, including the embedding of neoliberalism internationally in a new constitutionalism with credible commitments to corporate social responsibility (Gill 1995; Sum, this issue). However, while there are residual elements of this model in Nordic economies and Rhenish capitalism that undertake pragmatic neoliberal policy adjustments, it is absent where neoliberal regime shifts have occurred. This is partly related to the fact that, whereas Ordoliberalism is concerned with maintaining economic stability and social cohesion, the forces presiding over neoliberal regime shifts are seeking to disrupt established institutions and promote creative destruction in a one-sided manner that privileges profits over social cohesion and sustainable development. Even more significantly, the neoliberal project in general and financedominated accumulation in particular are not so much associated with the efficient organization of the circuits of capital and successful competition in free markets (as neoliberal rhetoric might suggest) as with different forms of political capitalism. Here, 
following Max Weber, profits are tied variously to "unusual deals with political authority", to resort to force and domination, or to predatory forms of accumulation (on this distinction, see Weber 1965; and, for commentary, Swedberg 1998).

This undermines the historical relation in normal conditions between profit-oriented, market-mediated capitalism and liberal bourgeois democracy (Jessop 2017). In particular, capitalism's elective affinity with liberal democracy is weakened when profits derived from financial speculation and risk-taking start to exceed those that come from the financial intermediation and risk-management activities that are essential to the circuits of productive capital. The affinity is further weakened where finance-dominated accumulation leads to growing inequalities in income and wealth due to deregulation, liberalization, and the interpenetration of economic (especially financial) and political power. Thus, when the inevitable serious financial crises occur because of the one-sided neoliberal emphasis on profits (exchange-value) over the substantive integration of the circuits of capital (use-value), underlying crisistendencies in the wider political and social order intensify, leading to crises of representation (splits between natural governing parties and the electorate), crises of legitimacy (distrust of the state and authorities), antagonism towards the rich and powerful, and a crisis of intellectual and moral leadership reflected in growing popular resentment, populist rhetoric, and the opening of political space for extremist movements. An early response to this were "Third Way" efforts to maintain neoliberal momentum by resorting to flanking and supporting measures without substantially modifying the main planks of the neoliberal project. As their failure became evident in the light of the North Atlantic Financial Crisis and its management in the interests of financial capital, accompanied by greater austerity for the wider population, the organic crisis of neoliberalism intensified. In particular, neoliberal regimes used their exceptional powers to rescue insolvent financial institutions rather than to nationalize them or allow normal bankruptcy procedures to be implemented; and they responded to popular dissent by stepping up surveillance, engaging in pre-emptive policing, and, on occasion, resorting to paramilitary suppression of open dissent (cf. Boukalas 2014).

These trends have been identified and named by political scientists and political economists from diverse positions on the right as well as centre and left. For 
example, Greg Albo and Carlo Fanelli (2014) refer to a new phase of bipartisan or pluripartisan "disciplinary democracy" as the political form of "permanent austerity" (cf. Rasmus 2010, Stützle 2013). lan Bruff (2013) talks of neo-liberal authoritarian constitutionalism; Ingar Solty (2013) identifies an authoritarian crisis constitutionalism oriented to the economic governance of competitive austerity; and Lukas Oberndorfer (2015) explores the rise of authoritarian competitive statism. From a social democratic perspective, Wolfgang Streeck (2014) refers to a move from the welfare state to the consolidation state; and a (former) Fabian Socialist, Colin Crouch, describes the transition to post-democracy (2004). On the libertarian right, there is condemnation of the strong and repressive state that emerges from allegedly unconstitutional intervention to shore up finance capital and police dissent (e.g. Stockman 2013). While these are still not mainstream views, such claims do prompt the question whether these trends are short-term aberrations, conjunctural states of emergency, or precursors of a "new normal".

Putting that question aside for the moment, these developments, have fuelled growing, if still fragmented, resistance and growing anger about economic and political linkages among interest-bearing capital, politicians, and state managers. The best-known expressions of this resentment were for a while the Occupy Movement with its slogan of the $99 \%$ and the $1 \%$ and the Astro-turf "Tea Party" movement in the USA, which prepared the ground for the election of President Trump. Another manifestation was, of course, the rise of the United Kingdom Independence Party and the miscalculations on the part of the British establishment that led to the Brexit referendum.

\section{Towards an Enduring Austerity State}

While austerity policies differ across "varieties of capitalism", they are also shaped by interdependencies that result from interstate relations (including forms of regional and global governance), foreign trade (and other features of world market integration), and the prevailing logic of the world market. This highlights the need to examine austerity in terms of the economic and political linkages, including their basic forms and institutional architecture, and their mediation through the changing balance of forces. 
The well-known policy-politics-polity triplet suggests that austerity can be studied in three ways. First, there are conjunctural austerity policies that are introduced in the first instance as temporary measures in response to short-term or immediate problems. As the conjuncture becomes favourable again, these policies are suspended or reversed. Second, there is the enduring politics of austerity (often called "permanent austerity" in the relevant literature) that is promoted in response to a "chronic" crisis, real or manufactured, in the fisco-financial domain and/or in the economy more generally. This characterizes several stages of neoliberal regime shifts, which, in contrast to pragmatic neoliberal policy adjustments, are intended to bring about a more lasting reorganization of the balance of forces in favour of capital. Third, associated with stages five to seven, there is the austerity polity. This results from a continuing fundamental institutional reorganization of the relations between the economic and political in capitalist formations.

Whereas conjunctural policies are found in the pattern of neoliberal policy adjustment and associated with targeted cuts in specific areas, an enduring politics of austerity is characteristic of neoliberal regime shifts and assumes the form of general fisco-financial restraint, putting downward pressure on most areas of expenditure, especially discretionary ones (Jessop 2002; Taylor-Gooby 2013; Seymour 2014). This pattern can be triggered by an obvious crisis, one that is deliberately exaggerated, or one "manufactured" for political purposes. Indeed, in neoliberal regimes, whatever the state of the economy, it is always deemed to be the right time to reduce public expenditure (except for corporate welfare) through an appropriately crafted (and crafty) politics of austerity. This involves far more than quantitative cuts in spending because it is also intended to have qualitative, transformative effects. It is pursued as a means to consolidate and extend the power of capital, especially interest-bearing capital, and to subsume ever wider areas of social life under the logic of differential accumulation. It becomes a major vector of the colonization, commodification, and, eventually, financialization of everyday life processes subject to friction, resistance, and crisis-tendencies.

Seymour (2014) argues that austerity involves something much broader and more complex than spending cuts - thanks to its role in restructuring, recalibrating, and 
reorienting state expenditure. Indeed, for him, austerity is the dominant political articulation of the global economic crisis in Europe and North America. This strategy has seven aspects: (1) rebalance the economy from wage-led to finance-led growth; (2) redistribute income from wage-earners to capital; (3) promote "precarity" in all areas of life as a disciplinary mechanism and means to reinforce the financialization of everyday life; (4) recompose social classes, with growing inequality in income and wealth and greater stratification within classes; (5) facilitate the penetration of the state by corporations; (6) accelerate the turn from a Keynesian welfare state based on shared citizenship rights to a workfare regime that relies on coercion, casual sadism, and, especially in the US, penality; and (7) promote the values of hierarchy and competitiveness (Seymour 2014: 2-4). In many respects, these aspects were already inscribed in the politics of neoliberal regime shifts but, for Seymour, they were reinforced after the 2007-9 financial and economic crisis. This can be explained in part by the fact that the painful measures already taken to consolidate budgets in the 1990s and early 2000s were wiped out by the impact of the North Atlantic Financial Crisis and the Eurozone crisis as governments took on more debt to bail out banks and/or create stimulus packages (Rasmus 2010; Hudson 2012).

This ramping up of the politics of austerity occurred in part because the response of financial capital to this crisis intensified the state's fisco-financial crisis. Measures were taken to rescue interest-bearing capital from the effects of its Ponzi dynamic and from the inherently unsustainable drive for financial profits (see above; also Demirović \& Sablowski 2013; Elsner 2012; Hudson 2015). This created a debtdefault-deflation dynamic that has worsened public finances as well as the private sector (Rasmus 2010). In addition, as Seymour, among others, notes, the politics of permanent austerity is not just a response to economic crisis but also to political and ideological crises and, indeed, an organic crisis of the capitalist social order (Seymour 2014: 4; cf. Gramsci 1971; Bruff 2013). This is used to justify a state of economic emergency that is presented initially as a "temporary" response to immediate or chronic problems but then acquires more permanent form through cumulative and mutually reinforcing institutional change, routinization of exceptional measures, and habituation. 
Overall, then, the politics of austerity can be interpreted as a long-term strategic offensive to reorganize the institutional matrix and balance of forces in favour of capital. It aims to rearticulate relations between (1) the social power of money as capital and of capital as property and (2) the political power of the state. Inter alia, this involves a politics aimed at disorganizing subaltern classes and reorganizing the capitalist power bloc around interest-bearing capital (in neoliberal regimes) and export-based profit-producing capital (in economies where neoliberal policy adjustments prevailed). In the Eurozone, for example, the central goal of authoritarian crisis constitutionalism is to deepen EU integration on neoliberal terms and govern through competitive austerity. Its several aims include socializing bank losses; exploiting the sovereign debt crisis to restructure welfare states and labour markets (including further measures to weaken trade union bargaining power) and to impose shock therapy in the periphery. In both finance-dominated and exportoriented regimes, the overall approach can switch between offensive and defensive tactics (an example of the latter is the "Third Way"). The successful pursuit of this strategy, which cannot be taken for granted, leads to an austerity state embedded in a political system (polity) that institutionalizes a 'permanent' politics of austerity.

\section{Conclusions}

This article has described four main types of neoliberalization, none of which exists in pure form, and which should be explored in their complex interrelations in timespace. In this sense, just as serious comparative and historical research should eschew the false choice between studying varieties of capitalism and positing an overarching world system logic and explore variegated capitalism (Jessop 2014), we should avoid thinking in terms of separate varieties of neoliberalism or attributing a global logic to neoliberalization. If there are commonalities at a global scale, these emerge from the interaction of multiple forms and sites of neoliberalization in a variegated world market. In addition, the very heterogeneity of neoliberal projects, the social forces advancing or resisting them, and their inherent contradictions and barriers mean that this is a messy process (cf. Peck and Theodore 2012). On this basis, I proposed a logical-historical approach to the periodization of neoliberal regime shifts, abstracting from the wider pattern of variegated neoliberalization. Like the typology, it is based on theoretical considerations and historical observation 
(hence its logical-historical label) and, when applied in case studies, would aim to show the contingently necessary uniqueness of each case as well as reveal certain commonalities. The third main step in the argument was to consider the political framework (political society + civil society) within which neoliberal regime shifts have been pursued and the effects of this pursuit on the nature and crisis-tendencies of the state. The next two steps examined the distinctive features of the financedominated accumulation that is privileged by neoliberalization and its association with a state of enduring austerity. This involves in turn the consolidation of authoritarian neoliberalism as the "best possible political shell" for a still evolving, and inevitably crisis-prone, predatory, finance-dominated accumulation regime. It remains to be seen whether the many fragmented forms of resistance can be linked up horizontally, vertically, and transversally to provide an effective challenge to this new bloc, its finance-dominated accumulation regime and its "new normal" state form by exploiting their fragilities. This will require connecting economic and political power in ways that are "proscribed" by the democratic rules of the game but are realized continually in non-democratic ways by the new transnational financial bloc.

\section{References}

Albo, Greg and Carlo Fanelli. 2014. "Austerity against Democracy. An Authoritarian Phase of Neoliberalism?" SocialistProject.Canada. www.socialistproject.ca/documents/AusterityAgainstDemocracy.pdf

Black, William K. 2014. "Posing as Hyper-Rationality: OMB's Assault on Effective Regulation". New Economic Perspectives 27 May.

Boukalas, Christos. 2014. Homeland Security, its Law and its State: A Design of Power for the $21^{\text {st }}$ Century. London: Routledge.

Bruff, Ian. 2013. "The Rise of Authoritarian Neoliberalism”. Rethinking Marxism 26: 113-29.

Crouch, Colin. 2004. Post-Democracy. Cambridge, UK: Polity Press.

Demirović, Alex and Thomas Sablowski, Thomas. 2013. The Finance-Dominated Regime of Accumulation and the Crisis in Europe. Berlin: Rosa Luxemburg Stiftung.

Duménil, Gérard and Dominique Lévy. 2011. The Crisis of Neoliberalism. 
Cambridge, MA: Harvard University Press.

Elsner, Wolfram. 2012. "Financial Capitalism - at Odds with Democracy: The Trap of an 'Impossible' Profit Rate”. Real-World Economics Review 62: 132-59.

Fine, Ben. 2010. “Locating Financialization”. Historical Materialism 18: 97-116.

Gill, Stephen. 1995. "The Global Panopticon? The Neo-liberal State, Economic Life and Democratic Surveillance". Alternatives 20: 1-49.

Gramsci, Antonio. 1971. Selections from the Prison Notebooks. London: Lawrence \& Wishart.

Hall, Stuart et al. 1978. Policing the Crisis: Mugging, the State, and Law and Order. London: Macmillan.

Hudson, Michael. 2012. The Bubble and Beyond: Fictitious Capital, Debt Deflation and the Global Crisis. Dresden: ISLET.

Hudson, Michael. 2015. Killing the Host: How Financial Parasites and Debt Bondage

Destroy the Global Economy. Dresden: ISLET.

Jessop, Bob. 2002. The Future of the Capitalist State. Cambridge, UK: Polity. Jessop, Bob. 2014. "Capitalist Diversity and Variety: Variegation, the World Market, Compossibility and Ecological Dominance”. Capital \& Class 38, no 2: 43-56. Jessop, Bob. 2015. "Neo-liberalism, Finance-Dominated Accumulation, and the Cultural Political Economy of Austerity". In Social Policy in Times of Austerity: Global Economic Crisis and the New Politics of Welfare, edited by Kevin Featherstone \& Zoe M. Irving, 87-112. Bristol: Policy Press.

Jessop, Bob. 2016. "The Heartlands of Neoliberalism and the Rise of the Austerity State". In Simon Springer, Kean Birch, and Julie MacLeavy (Eds), The Handbook of Neoliberalism, 410-21. London: Routledge.

Jessop, Bob. 2017. "Variegated neoliberalism, finance-dominated accumulation, and citizenship rights", in The Transformation of Citizenship, vol. 1, edited by Jürgen Mackert and Bryan S. Turner, 13-30. London: Routledge.

Jessop, Bob et al., 1988. Thatcherism: A Tale of Two Nations. Cambridge, UK: Polity.

Krippner, Greta R. 2005. "The Financialization of the American Economy”. SocioEconomic Review 3: 173-208.

Lapavitsas, Costas. 2013. Profiting without Producing: How Finance Exploits us All.

London: Verso.

Oberndorfer, Lukas. 2015. "From New Constitutionalism to Authoritarian 
Constitutionalism". In Asymmetric Crisis in Europe and Possible Futures, edited by Johannes Jäger and Elisabeth Springler, 184-205. London: Routledge.

Peck, Jamie and Theodore, Nik. 2012. "Reanimating Neoliberalism: Process Geographies of Neoliberalization”. Social Anthropology 20, No. 2: 177-85.

Poulantzas, Nicos. 1978. State, Power, Socialism. London: NLB.

Rasmus, Jack. 2010. Epic Recession: Prelude to Global Depression. London: Pluto. Seymour, Richard. 2014. Against austerity: How We Can Fix the Crisis They Made. London: Pluto.

Smith, Yves. 2010. Econned. How unenlightened self-interest undermined democracy and corrupted capitalism. Basingstoke: Palgrave-Macmillan.

Solty, Ingar. 2013. "Is the Global Crisis ending the Marriage between Capitalism and Liberal Democracy?" In Political Power Reconsidered. State Power and Civic Activism between Legitimacy and Violence, edited by Maximilian Lakitsch, 161204. Berlin: LIT Verlag.

Stockman, David. 2013. The Great Deformation. The Corruption of Capitalism in America. New York: PublicAffairs.

Streeck, Wolfgang. 2014. Borrowed Time. London: Verso.

Swedberg, Richard. 1998. Max Weber and the Ideas of Economic Sociology.

Princeton, NJ: Princeton University Press.

Stützle, Ingo. 2013. Austerität als politisches Projekt. Von der monetären Integration Europas zur Eurokrise. Münster: Westfälisches Dampfboot.

Taylor-Gooby, Peter. 2013. The Double Crisis of the Welfare State and What We Can Do about It. Basingstoke, UK: Palgrave.

Weber, Max. 1965. Economy \& Society. New York: Bedminster <1922>.

Will, Susan, Stephen Handelman, and David Brotherton, eds. (2013). How they Got away with It: White Collar Criminals and the Financial Meltdown, New York: Columbia University Press. 